\title{
Vocations and Learning Volume 5, Issue 1 April 2012
}

Published online: 28 July 2012

(C) Springer Science+Business Media B.V. 2012

The Vocations and Learning Journal would like to inform its readers that Guest Editorship does not occur in Vocations and Learning. Consequently, In this regard, the print version of the Special Issue Volume 5, Number 1 / April 2012, which listed Karen Littleton as Guest Editor, is incorrect. Karen Littleton (Open University, United Kingdom) is a Special Issue Organizer of Volume 5, Number 1, April 2012 Issue, along with Stephanie Taylor (Open University, United Kingdom) and Anneli Eteläpelto (Jyvaskyla University, Finland). 